\title{
The Manuscript Literature as a Permanent Element of the Cultural Heritage and Determinant of the Identity of the Tatar Community in Poland
}

\author{
Magdalena Lewicka
}

\begin{abstract}
The paper discusses the writings of the Tatars of the Great Duchy of Lithuania in the context of its meaning as a solid element of the cultural heritage and the carrier of the identity of the Tatar society in territory of the Republic of Poland. The Author discusses the Tatar literary output including its genesis and development which are inseparably connected with the history of the Tatar settlement in the territory of the Great Duchy of Lithuania, the characteristic features which had given it a one of a kind character, as well as classification of the works belonging to this culture on the basis of the criteria of the form and content which allows us to specify several kinds of manuscripts. The Author indicates not only the literary value of the Tatar writings, but also their great meaning as a source material for scientific research of various character: philological, historical, ethnographical, cultural and religion studies, but also the great role they play as a basic binder allowing the Tatar society to maintain the ethnical difference and cultural identity which-in the light of a multilayered assimilation in the Christian surroundings-was mostly identified by their denomination, Islam.
\end{abstract}

Index Terms-The Tatars of the great duchy of Lithuania, cultural heritage of the Tatars, the manuscript literature of the Tatars.

\section{INTRODUCTION}

The development of the Tatar literary manuscripts and its unique character are inseparably connected with the history of the settlement of this tribe originating from the steppes of Mongolia in the territory of the Grand Duchy of Lithuania. Its outset dates back to the time of king Gediminas reign (1305-1341), the first reference to Tatars living in Lithuania appears in the chronicles of the Italian Franciscan, Lucas Wadding: "Our brothers departed to proclaim the teachings of Christ in the Lithuanian lands, where they found a whole nation engulfed in the barbarian errors and dedicated to the cult of fire, among them the Scythians, coming from the country of a khan, who use Asian language in the prayers" [1], while the first information about Tatars with the name of this ethnic group is noted in Jan Długosz chronicle: "Alexander or Vytautas the Duke of Lithuania, having reconciled with Svitrigaila, wanted to prove himself to be a Christian duke, embarked on the first raid against the Tatars. He attacked the main settlement of them, called the Horde, and many thousand barbarians with their wives, children and cattle were taken to Lithuania" [2]. The Tatar settlement proceeded in two main stages, the first of them occurring in

Manuscript received March 3, 2016; revised May 21, 2016.

M. Kubarek is with the Nicolas Copernicus University in Torun, Department of Arabic Language and Culture, Poland (e-mail: magdakubarek@poczta.onet.pl). $14^{\text {th }}$ and $15^{\text {th }}$ centuries was connected with the flow of the Tatars from the empire of the Golden Horde and khanates located on the banks of Volga River. This migration movement was based on the compulsory islamization conducted by Uzbeg Khan (1312-1342). In the end, migration to the west of Asia had not protected the Tatars from Islamization. The development of the Tatar settlement of this period can be attributed to the Grand Duke of Lithuania - Vytautas (1392-1430), who granted Tatars the land and privileges (guaranteeing the freedom of religion at the same time) in exchange for military service and help in fighting the Teutonic knights, which contributed to the massive relocation to Lithuania. The second stage of the settlement occurred between $16^{\text {th }}$ and $18^{\text {th }}$ centuries, at first due to the settling of the war prisoners captured during the war with the Crimea Horde, and then because of the migration of the civilians from Kazan and Astrakhan Khanates fleeing from the Russian occupation. By the end of the $17^{\text {th }}$ century the Tatars settled in the territory of the Crown where king John III Sobieski granted them the demesnes in Podlasie district. After the partitions and fall of the Republic of Poland the majority of territories settled by the Tatars became the part of the Tsardom of Russia, after World War I (apart from the Kaunas province belonging to the Republic of Lithuania) it was within the territory of the independent Poland. After World War II, when the Kresy (Eastern Borderlands) were lost by Poland the Tatars have been living in territory of Poland, Lithuania and Belarus [3]. Six hundred years' long presence in these territories (including 350 years within the current borders of Poland) made them a part of Polish nation, in particular distinguishing themselves in the military history of the Republic of Poland by participation in the fight for freedom, independence and playing an important part in all the major military events in the history of Poland (Thirteen Years' War (1458-1466), the raid of Vladislaus II of Hungary to Czech Republic (1471), battles of Buczyna (1588), Cecora (1620), Chocim (1621), Beresteczko (1651), PolishSwedish war (1655), Bar Confederation (1768-1772), Kościuszko Uprising (1794), November Uprising (1830) January Uprising (1863), World War I and II).

While the history of Tatar settlement in the territory of the GDL is quite well recognized and discussed in detail by historians and orientalists, the aspect of the genesis of the country's Muslim citizens remains obscured, since no relics of the literature dated from the earliest period have been preserved, and the first text recognized by the scholars which is describing the Tatar society does not mention any literary activity (hence it can be deduced that Tatar books had not been written at that time) gives rise to authenticity reservations [4]. On the basis of indirect presumptions textological and philological analysis of the content and 
research on the historic context (including the influence of reformation and counter-reformation) [5] - it can be assumed that the birth of the Tatar literary manuscript occurs in the second half of the $16^{\text {th }}$ century. One of the first works is the translation of the Quran of the second half of 16 th century, which in accordance with the Islamic rule of $i \quad z$, forbidding the translation of the Holy Book, took the form of a tafsir (comment, explanation), while the moment concluding the process of formation and development of the Tatar manuscript output was the end of 18th century.

Among the factors which are considered to be the reasons for its shaping, one can mention the process of the linguistic assimilation, which caused the Tatars who were the ethnic, cultural and religious minority of the new country to lose the command of their own language (Turkic dialects) and oriental languages facilitating contacts with their coreligionists (Turkish) and religious practices (Arabic) for the languages functioning in the GDL - Polish and Belorussian. Probably the process of the linguistic assimilation of the Tatar community was based on the fact that that its members varied as far as the origin is concerned and used different dialects, which in the light of the lack of the earlier developed feeling of the ethnic community (such a community was not created until the period of the GDL, and its joining element was not the ethnical and linguistic factor, but a political ones, made these languages (dialects) originated in the steppes were not a unifying determinant, especially due to the fact that they were not the carriers of the religious traditions [6]. The process which had been progressing since the $15^{\text {th }}$ century and ended in the second half of the next century was one of the causes for undertaking the activities regarding the translation of the religious books into Slavic languages used by Tatars, since on the one hand the doctrinal issues forced them to use the Arabic texts in the rites and liturgy, and on the other hand these texts became-in the conditions of the isolation from the sources and roots of Islam-the only carrier of their religious knowledge. These books were to become the basic binder allowing the GDL Tatars to retain their ethnic distinctiveness and cultural identity [7], which in $17^{\text {th }}$ century had been-as it seems-identified exclusively by their faith-Islam. Another factor which had certain influence on shaping and development of the Tatar literary output was, undoubtedly, the historical context, namely the cultural and spiritual revival of the Republic of Poland connected with the Renaissance and the Reformation which caused the Tatar society to create their own literature reflecting its distinctiveness and providing the central part of their cultural heritage.

\section{Characteristic Features of the Literary MANUSCRIPTS OF THE GDL TATARS}

Characteristic features of the literary output of the GDL Tatars can be brought down to a few main issues, starting from the manuscript-like form of the books and anonymity of the authors, through multilingualism, reflected in the presence of the Slavic (Polish and Belarusian) and oriental (Arabic, Turkish and Persian [linguistic layer, as well as heterogenic character (referring to the volume, genologic classification and themes) to the element distinguishing this literature to the largest extent, namely-the way of notation, consisting in the exclusive usage of the Arab alphabet to write down the texts forming the content of the books.
Two factors decided about the manuscript-like character of the Tatars' literary output. The first of them, particularly significant, was surely the reference to the literary output present in the world of Islam, especially regarding the religious literature, which due to the high rank of the calligraphy was subjected to the printing process, and has been the key form of art. In the context of the religious texts manual copying of the books became ritual in form. Additionally, the manuscript form was favoured by the local cultural context, namely the return to the manuscripts characteristic for the period of Sarmatism.

Anonymity, as a typical feature of all the manuscript literature, is also characteristic for the discussed Tatar works. Only two names of authors, regarding these works, are known: Hodyna (Kitab of 1645.) and Uriah son of Ismail (Tafsir dated for 1686), as opposed to the scribes who often disclosed their names in colophons. Surely, bearing in mind the excellent command of Arabic and other oriental languages and the general erudition of the Tatar authors, resulting from the character of their work, including the compilation and adaptation of the texts of Slavic and Middle Eastern provinence, they were the representatives of the intellectual elite of the Tatar society. What is significant in this context, the impossibility of discovering their personal information, and the following anonymous character of the Tatar literary output implicates a major hindrance in the process of chronological definition, which can only be based on the indirect presumptions (philological and contextual analysis, dates of the subsequent copies of the books, historical, social context, etc.) [8].

Both Polish and Belarusian language present in the Tatar manuscripts do not occur in the pure form. While the former usually has the form of the northern Kresy borderland dialect arisen on the border of the Belarusian linguistic area, the latter contains numerous inclusion of Polish origin. The Slavic layer contains numerous borrowings and oriental influences (Turkish-Tatar, Arabic, Persian) first of all in the range of lexis and phraseology regarding the rites and religion [9].

Oriental texts present in the literary manuscripts of Tatars are in the first place connected with the lithurgy and prayer body (mostly verses and surahs of the Quran in Turkish and Arabic, as well as Arabic and Turkish prayer formulas). The Arabic linguistic layer has not been subjected to a deeper analysis so far (scholars of Polish and Belarusian concentrated on the Slavic layer). Research works covering this issue have been undertaken by the author of this paper [10].

This way of notation based on the usage of the Arabic alphabet to write down the texts of the Oriental and Slavic layer was the reference to the writing culture, mostly of the religious character present in the world of Islam. Adaptation of the Arabic alphabet instead of the Slavic writing was caused by the particular respect given to religious books, since the sacral value not only covered the content, but also the form, including letters used to write down the Quran. The Arabic alphabet was also functioning outside the Tatar literary manuscripts, namely the grave epitaphs, sacral ornamentation, and often in private writings (letters, documents, signatures), all the more that the Tatars preserved the ability to use the Arabic writing until $20^{\text {th }}$ century, even though their excellent command of this language was lost in the course of centuries. What is 
particularly significant in this context, the Arabic alphabet must have been adopted to write down the Slavic texts, or to be more precise the phonologic system of these languaged through the introduction of the additional graphems and change of the phonetic value of some existin letters [11].

It seems that adopting the classification proposed by Drozd [12] seems to be the most justified for the detailed and clear characteristics of the Tatar literary output. It is based on the criteria of the content and the form, which allows the delineation of the following types of the manuscripts: basic books including the manuscripts of The Quran, tafsirs, kitabs and chamails; auxiliary books including tajwids, sufras, vocabularies, amulets represented by dalawars, hramotkas and nuskas, and finally the last group: tables and muhirs. In the content of the Tatar manuscripts one can distinguish two, varied by the authors, types of texts: the first group consists of the texts in Polish and Belarusian, created, compiled, adapted and translated by Tatars, while the other includes texts in the oriental languages, borrowed from the eastern languages [13].

Manuscripts of The Quran (ar. Al-Qur'ān "recitation") [14] -are among the most popular, apart from chamails (prayer books) Tatar relic manuscripts whose basic element is the full text of the Holy Book of Islam in Arabic, enriched by sets of prayers (ar. $a l t$ ) and guidelines regarding the rules of the recitation (ar. ta wid, til wa), placed in the first and the last pages. Sometimes, apart from the above mentioned content components, additional information occur, such as the list of intentions (ar. niyya), where the appropriate verses of The Quran were to be recited (ar. ayāt al-Qur'ān), or the text of the $36^{\text {th }}$ surah YaSin. Manuscripts of The Quran usually number 200-300 pages, of the dominant size of $20 \times 17 \mathrm{~cm}$. In $19^{\text {th }}$ and $20^{\text {th }}$ centuries they were owned by the majority of the Tatar families and were passed down from generation to generation.

Tefsirs (ar. tafsīr "comment, explanation") [15] - are quite vast works containing the full text of The Quran with the interlinear translation into Polish complemented with the exegetic layer. Similarly to the above described manuscripts of the Holy Book, the additional elements of the content include prayers and description of the ritual of The Quran recitation which are written on the opening and closing pages of the tafsirs. Due to the fact that these works often numbered 400-500 pages (of a set size of $35 \times 20 \mathrm{~cm}$ ) they were often ordered by a whole group of "parishioners" as a wakf (ar. waqf) for the mosque. What's quite relevant, up until the appearance of the Polish translation of The Quran in 1858, these works had remained the basic source of the Tatars' knowledge on the content of the Holy Book.

Kitabs (ar. kitāb - "book, booklet") [16] - are the relics of the manuscripts of a varied content and volume, being a type of reading matter playing educational role, usually dealing with religious matters. They contain the stories of prophets (ar. anbiy ) and other renowned characters of Islam, stories based on the Muslim traditions (ar. sunna), apocrypha, The Quran (ar. Al-Qur n) and the Holy Bible (ar. Al-In l), eschatological visions, moralizing, devotional and prayer texts, hadiths (ar. ad ), comments to some surahs of The Quran, descriptions of rites and rituals (arfar $i$, ark $n$ ad-d $n$ ), elements of the Muslim law (ar. ar a), religious discussions, magic texts, vocabularies of Turkish and Arabic, tajwids (ar. $t a$ wid ), and rarely, non-religious texts among which the oriental and
Old-Polish texts dominate. Kitabs usually number 150-300 pages, and their sizes usually range from $35 \times 20 \mathrm{~cm}$ to $20 \times 17 \mathrm{~cm}$. In the $19^{\text {th }}$ and $20^{\text {th }}$ centuries, books of this type were owned by one per few or even several Tatar families.

Chamails (ar. amā'il-'something one carries with themselves") [17] - are decidedly the most popular kind of Tatar manuscripts, bearing some features of a prayer book, and what follows containing various texts of religious themes: practical descriptions of the Muslim rituals, including ablutions (ar. wu ), prayers, rits of the cycle of life, name giving (ar. $n$ ), circumcision (ar. it $n$ ), wedding (ar. zaw ), sets of Arabic and Turkish duai prayers (ar. $d u^{\prime} \bar{a}^{\prime}$ ), occasional formulas and devotional texts

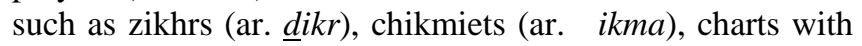
Muslim calendar (at-taqw $m$ al-hi $r$ ). Quite often chamails contained magic texts: prayers for chanting (curing the psychical diseases with the exorcisms), prognostics of fa'l $\left(f a^{\prime} l\right)$, short prayers and magical-curing formulas talsims (ar. ilsam). Classifying the chamails regarding the content and purpose, two types can be distinguished: mullahian serving mullahs to do rituals and for fałdżejs (people specializing in sorcery) to do magic and fortune telling. However, very rarely do they occur in the pure form, usually they are of universal character, including both the elements of the communal rites and magical practices and the individual rites and prayers. Chamails contain 100-300 pages, their dominant sizes are $10 \times 8 \mathrm{~cm}$ or $15 \times 10 \mathrm{~cm}$. In the $19^{\text {th }}$ and $20^{\text {th }}$ centuries each Tatar family possessed one or more prayer books.

Tajwids (ar. $t a$ wid- "the The Quran recitation learning") [18] -are particular type of the lectures in Turkish explaining the rules of articulation (ar. qir a) and recitation (ar. til wa) of the Holy Book of Islam with the interlinear Polish-Belorussian translations. Books of this type occur sporadically, sometimes they comprise an additional element of the content of other relics of Tatar literary manuscripts such as kitabs and chamails.

Sufras (ar. sifr - "book") - are small manuscripts containing a thirtieth part of the The Quran (ar. uz ), a type of didactic booklets used for teaching the children and prayers for the dead during the night preceding the funeral (ar. al tal- an za).

Vocabularies (the name given by the scholars) - are the manuscripts containing-in accordance with the etymology of the name-lexical resources, phrases and expressions together with their translations into Polish and/or Belarusian.

Dalawars (tur. $d u$ 'ālar-"prayers, collection of prayers") [19] -are the prayer scrolls put in the grave together with the deceased and they are the most lively type of the Tatar literary manuscripts since they function up till today. They consist of the excerpts of the The Quran (chosen surahs and verses) and the principles of the faith (ar. $m n$ ), penitential prayers $(t a w b a)$ and deliverance prayers $\left(d u^{\prime}(\bar{a})\right.$, which are to support the dead in the positive outcome of the Final Judgement (ar. Yawm ad-D n, Yawm al- is b). The main part (5-15m long and $8-15 \mathrm{~cm}$ wide), folded into a flat package or scrolled is put directly on the body right after it is put in the grave, while the additional parts, so called nuskas (ar. nus a) in the form of small cards which are put on the dead man's forehead, mouth, chest and in their hands; slightly bigger fragments-muhirczyks-are nailed overhead to the planks fitted on the walls of the grave and hanged at the height of the dead man's chest on the perpendicular stick fixed to the wall of the grave. 
Hramotkas (Belarusian: "writing, small writing") [20] are the prayer scrolls worn by living people, and most rifely-apart from chamails and dalawars-represented relics of literary manuscripts of Tatars. They are also called dalawars, like the scrolls lay in the graves (they are made in a similar way and after being folded into a small package, they are worn in a little holder placed under the right arm), hence the division into funeral (sepulchral) and protective dalawars. Hramotkas, whose length is usually 2-6 m and width is $4-12 \mathrm{~cm}$, contain the protective The Quran verses, principles of faith, prayers (ar. $d u^{\prime}\left(\bar{a}^{\prime}\right)$ ensuring the forbearance of sins and success in the temporal life, magic formulas and shapes-talismans (ar. ilsam). Among the protective dalawars a particular group consists of children's hramotkas, additionally containing the formulas protecting from the diseases and handed to children during the name giving celebration.

Nuskas (ar. nus a "piece, manuscript") [21] - are relics of the Tatar literary manuscripts whose character is close to hramotkas, they are often referred to as duajkas (ar. $d u$ ' $\bar{a}$ '), since they come in the shape of small pieces of paper containing the excerpts from the chamail-texts of Arabic prayers, protective or healing magic formulas and shapes. They are worn in holders hanged at various parts of the body or nailed over the door-frames and dug under the doorsteps.

Muhirs (tur. muhr-"stamp") [22] - are the ornate cards of fabric pieces containing the inscriptions or pictures of items, buildings, or places of sacral or magical character. Their function was ornamental, enriching the interiors of the houses and temples; and magic, protecting the houses and their residents. In the content of muhirs, there is a dominating motif of the text of an inscription (descriptions of rituals, prayer texts, chosen The Quran verses with their translations, ethical guidelines) or presentations of the holy places accompanied by calligraphic, geometric, plant-based, architectural motifs or Muslim emblems, hence the classification according to the me criteria dividing them into inscriptional muhirs and presentation muhirs. Separate group consists of the relics whose content is in accordance with the etymology of the name-stamp muhirs, however, these occur most rarely.

Tables (the name given by the scholars) [23] - are paper or cardboard boards of the didactic and devotional character, placed in houses or mosques, resembling muhirs both in the form (board, sometimes framed), usage (hanged on the wall) and the content (descriptions of the rites, prayer formulas, chosen verses from the The Quran with the translation, ethical guidelines).

\section{CONCLUSION - THE MEANING OF THE RELICS OF THE GDL TATARS LITERARY MANUSCRIPTS}

Manuscripts of the Tatars of the GDL, being the most important and richest part of their heritage and a sustainable remnant of the Tatar settlement in the territory of the Republic of Poland, have been recognized as a particular aspect, a phenomenon of a kind, to which a great spiritual, literary and cultural value is ascribed. On the one hand, it is indeed an extremely rich literary output-an individual, separate literature with features which are difficult to be encountered in the literary heritage of other nations or ethnic groups. On the other hand, however, it remains a proof of a close connection between the multi-layered culture of the Great Duchy of Lithuania and the civilization of Islam, which is expressed in the extraordinary fusion of the seemingly opposed and mutually excluding elements, yet perfectly coinciding in social life and in the literary output of Polish and Lithuanian Tatars, namely-the oriental Muslim culture with Christian culture. Finally, it is a particularly valuable source of the research material, not only of philological character (due to the presence of the unexplored grammar and lexical layers of the Polish language of the northern Kresy borderlands from the period from $16^{\text {th }}$ to $20^{\text {th }}$ century, as well as interference and transference processes within the Slavic languages and Slavic-oriental contacts on all linguistic layers), but also the basis for conducting interdisciplinary, historic, ethnographic, cultural and religious studies, as well as in the range of the history of art, since some of these relics of the literary manuscripts remain on the border of the literary output and religious art.

Leaving aside the literary value of this literature and its significance as research material, it has certainly become a major bond enabling the Tatar community to preserve its ethnic and cultural identity that - in view of the multifaceted assimilation in the Christian environment-was primarily identified through faith, i.e. Islam. That is why such as special spiritual and cultural role has been ascribed to the manuscript literature of the Tatars of the GDL as a permanent element of cultural heritage and vehicle of the identity of the Tatar community whose presence in Polish territories goes back 600 years.

\section{REFERENCES}

[1] P. Borawski, Tatarzy w Dawnej Rzeczypospolitej, Warszawa: LSW, 1986, p. 5.

[2] M. Łyszczarz, Młode Pokolenie Polskich Tatarów, OlsztynBiałystok: UWM, MZR, 2013, p. 74.

[3] A. Konopacki, Życie religijne Tatarów na ziemiach Wielkiego Księstwa Litewskiego w XVI-XIX w., Warszawa: Wydawnictwa UW, 2010, pp. 22-58.

[4] Risale-i Tatar-i Leh, polish translation by A. Muchliński, Traktat o Tatarach polskich,” Teka Wileńska, no. 4, pp. 241-272, 1858.

[5] C. Łapicz, "Z zagadnień przekładu muzułmańskiej terminologii religijnej na język polski i białoruski," in Krymsko-polskie zeszyty naukowe, A. Gadomski, Ed., Symferopol: Universum, 2005, pp. 165-179.

[6] C. Łapicz, "Losy językowe tatarów litewsko-polskich," Acta Universitatis Nicolai Copernici, no. 27, pp. 29-30, 52-54, 1986).

[7] A. B. Zakrzewski, "O asymilacji tatarów w rzeczypospolitej w xviXVIII w.," in Tryumfy i porażki. Studia z dziejów kultury polskiej XVI-XVIII w., M. Bogucka, Ed., Warszawa: PWN, 1989, pp. 76-96.

[8] A. Drozd, 2000, "Piśmiennictwo tatarów polsko-litewskich (XVIXX w.). zarys problematyki," in Katalog Zabytków Tatarskich. Piśmiennictwo i muhiry Tatarów polsko-litewskich, A. Drozd, M. M. Dziekan, T. Majda, Warszawa: Res Publica Multiethnica, pp. 24-25, 33-34.

[9] A. Drozd, "Piśmiennictwo Tatarów polsko-litewskich (XVI-XX w.). zarys problematyki," in Katalog Zabytków Tatarskich. Piśmiennictwo i muhiry Tatarów polsko-litewskich, A. Drozd, M. M. Dziekan, T. Majda, Warszawa: Res Publica Multiethnica, 2000, pp. 12-37.

[10] M. Lewicka, "Identyfikacja i analiza tekstologiczno-filologiczna arabskiej warstwy językowej pp. 478-485 Tefsiru z Olity (1723 r.),” in Estetyczne aspekty literatury polskich, białoruskich i litewskich Tatarów (XVI-XXI w.), G. Czerwiński, A. Konopacki, Ed., Białystok: Alter Studio, 2015, pp. 69-83.

[11] A. Drozd, "Piśmiennictwo Tatarów polsko-litewskich (XVI-XX w.). zarys problematyki," in Katalog Zabytków Tatarskich. Piśmiennictwo i muhiry Tatarów polsko-litewskich, A. Drozd, M. M. Dziekan, T. Majda, Warszawa: Res Publica Multiethnica, 2000, pp. 18-21.

[12] A. Drozd, "O twórczości literackiej tatarów w dobie staropolskiej," in Tatarzy w Europie i na świecie, Poznań 1995, pp. 33-47.

[13] A. Drozd, "Wpływy chrześcijańskie na literaturę tatarów w dawnej 
Rzeczpospolitej. Między antagonizmem a symbiozą," Pamiętnik Literacki, vol. 3, pp. 3-34, 1997.

[14] A. Drozd, "Piśmiennictwo tatarów polsko-litewskich (XVI-XX w.). Zarys problematyki," in Katalog Zabytków Tatarskich. Piśmiennictwo i muhiry Tatarów polsko-litewskich, A. Drozd, M. M. Dziekan, T. Majda, Warszawa: Res Publica Multiethnica, 2000, pp. 12-13.

[15] A. Drozd, "Piśmiennictwo Tatarów polsko-litewskich (XVI-XX w.). Zarys problematyki," in Katalog Zabytków Tatarskich. Piśmiennictwo i muhiry Tatarów polsko-litewskich, A. Drozd, M. M. Dziekan, T. Majda, Warszawa: Res Publica Multiethnica, 2000, pp. 13.

[16] A. Drozd, "Piśmiennictwo Tatarów polsko-litewskich (XVI-XX w.). zarys problematyki," in Katalog Zabytków Tatarskich. Piśmiennictwo i muhiry Tatarów polsko-litewskich, A. Drozd, M. M. Dziekan, T. Majda, Warszawa: Res Publica Multiethnica, 2000, p. 13.

[17] A. Drozd., "Piśmiennictwo Tatarów polsko-litewskich (XVI-XX w.). zarys problematyki," in Katalog Zabytków Tatarskich. Piśmiennictwo i muhiry Tatarów polsko-litewskich, A. Drozd, M. M. Dziekan, T. Majda, Warszawa: Res Publica Multiethnica, 2000, pp. 13-14.

[18] A. Drozd., "Piśmiennictwo tatarów polsko-litewskich (XVI-XX w.). zarys problematyki," in Katalog Zabytków Tatarskich. Piśmiennictwo i muhiry Tatarów polsko-litewskich, A. Drozd, M. M. Dziekan, T. Majda, Warszawa: Res Publica Multiethnica, 2000, pp. 14.

[19] A. Drozd., "Piśmiennictwo tatarów polsko-litewskich (XVI-XX w.). zarys problematyki," in Katalog Zabytków Tatarskich. Piśmiennictwo i muhiry Tatarów polsko-litewskich, A. Drozd, M. M. Dziekan, T. Majda, Warszawa: Res Publica Multiethnica, 2000, pp. 14-15.

[20] A. Drozd., "Piśmiennictwo tatarów polsko-litewskich (XVI-XX w.). zarys problematyki," in Katalog Zabytków Tatarskich. Piśmiennictwo i muhiry Tatarów polsko-litewskich, A. Drozd, M. M. Dziekan, T. Majda, Warszawa: Res Publica Multiethnica, 2000, p. 15.

[21] A. Drozd., "Piśmiennictwo Tatarów polsko-litewskich (XVI-XX w.). zarys problematyki," in Katalog Zabytków Tatarskich.
Piśmiennictwo i muhiry Tatarów polsko-litewskich, A. Drozd, M. M. Dziekan, T. Majda, Warszawa: Res Publica Multiethnica, 2000, pp. 15-16.

[22] A. Drozd., "Piśmiennictwo tatarów polsko-litewskich (XVI-XX w.) zarys problematyki," in Katalog Zabytków Tatarskich Piśmiennictwo i muhiry Tatarów polsko-litewskich, A. Drozd, M. M. Dziekan, T. Majda, Warszawa: Res Publica Multiethnica, 2000, pp. $38-43$.

[23] A. Drozd., "Piśmiennictwo tatarów polsko-litewskich (XVI-XX w.). zarys problematyki," in Katalog Zabytków Tatarskich. Piśmiennictwo i muhiry Tatarów polsko-litewskich, A. Drozd, M. M. Dziekan, T. Majda, Warszawa: Res Publica Multiethnica, 2000, pp. 16.

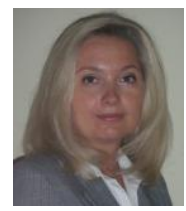

Magdalena Lewicka was born in 1973 in Toruń (Poland). She is a doctor of human sciences specializing in Arab philology, the director of Arabic Language and Culture Center of Nicolas Copernicus University in Torun; Arabic and Islamic scholar, Arabic language lecturer, sworn translator, graduate of Arabic and Islamic Department of the University in Warsaw, graduate of Administration and Management Studies at Trade Institute, Damascus University, and Arabic Language School for Foreigners in Damascus and Cairo. Member of Polish Orient Society, Polish Neophilology Society, Polish Society for the Study of Religion, Polish Society of Sworn and Specialised Translators. The author conducts research of Islamic and Arabic issues and language education (glottodidactics), author of numerous scientific and popular science publications, an editor of the books Christian and muslim dialogue. The Past and the present, threats and challenges (Toruń 2011), Christian and muslim dialogue. Key to a mutual future (Toruń 2012), Christian and muslim dialogue. Theory-practice perspectives (Torun 2013), Didactics of Teaching Arabic. Theory-practice - perspectives (Torun 2013), Didactics of teaching Arabic. Language receptive skills development (Toruń 2014), Didactics of teaching Arabic. Language receptive skills development (Torun 2015); Constants and Variables in the Arabian Literature (Torun 2014); The Middle East in a Process of Change, t.1 (2016); The Middle East in a Process of Change, t.2 (Toruń 2016). 